J. Perinat. Med. 14 (1986) 43

\title{
The technique of fibrin adhesion for premature rupture of the mem- branes during pregnancy
}

\author{
Kurt Baumgarten and S. Moser
}

Department of Obstetrics and Gynecology of The Wilhelminenspital (Municipal Hospital), Vienna, Austria

\section{Introduction}

Premature rupture of the membranes in pregnancy normally implies a considerable risk for mother and fetus. For example, for each 4,500 deliveries after premature rupture of the membranes, one maternal death must be expected [22]. For the total birth rate, due to premature rupture of the membranes and the resulting complications 1 maternal death should be expected for each 20,000 deliveries [3]. When adequate antibiotic protection is provided [16], in case of premature rupture of the membranes, pyrexia is probably not greater than in deliveries after rupture of the membranes at term. Although the child is jeopardized by prolapse of the cord and amniotic infection syndrome (AIS), the primary jeopardy is with premature birth and its resulting consequences. Perinatal mortality is 2 to 3 times higher than normal and predominantly affects neonates whose birth weight is less than $2,500 \mathrm{~g} \mathrm{[16].}$

The incidence of neurologic complications in preterm infants is directly proportional to the interval between rupture of the membranes and parturition [13]. Until recently one could not determine whether the development of RDS in preterm infants born after rupture of the membranes is either increased or decreased [4, $14,19,20,24]$.

The methods of preventing premature rupture of the membranes are rather limited. In the case of cervical insufficiency one of these is cerclage performed at the appropriate time.

Until recently there was no effective method to repair a spontaneously ruptured amniotic sac. The introduction of a human fibrin tissue sealant opens a possibility promising at least a certain measure of success.

The first attempts at sealing tissues date back to 1944 when CRONKITE [5] and TIDRICK [21] fixed skin grafts with human fibrin to wound area. Thirty years later the technique was revived and perfected by MATRAS and KUDERNA [18] who reported on successful neuroanastomosing in humans by the use of fibrin sealant in 1975 . Mainly for its hemostyptic and adhesive effect, the two-component fibrin sealant is being used more and more often in human medicine.

GENZ [7] was the first to report on the possibility of sealing amniotic leaks. In the meantime FetTig [6], ANGER [1], and LUDWIG [17] favored this technique. KURz and HUCH [15], in a small series attempted amniotic sealings, and reported only failures. The different opinions as to the role of the sealant in the closure of amniotic leaks may explain the search for the appropriate method for attaining this goal. GENZ believes that the real sealing of the amniotic leak is brought about by improved adhesion of the chorion to the decidua after fibrin application. At the same time, the fibrin clot should act as a barrier between uterus and 
vagina to prevent ascending infection, thus affording protection from AIS. Closure of the cervical canal itself is not to be expected, as tissue sealants cannot bridge the gap between epithelia. GENZ [7-12] reported 19 cases between 1979 and 1982 with a success rate of $60 \%$, which caused us to carry out investigations with the human fibrin sealant TissuCOL ${ }^{\circledR}$. We will report on 26 cases in this paper.

\section{Material and methods}

In 26 women between gestational weeks 18 and 36 , fibrin adhesion was attempted. In all these cases treatment was because of the mother's stated desire to have the child despite insufficient maturity of the fetal lungs. To determine this insufficiency the following 4 parameters were used: delta O. D. 650 , creatinine determination, count of orange-stained cells, and ratio determination.

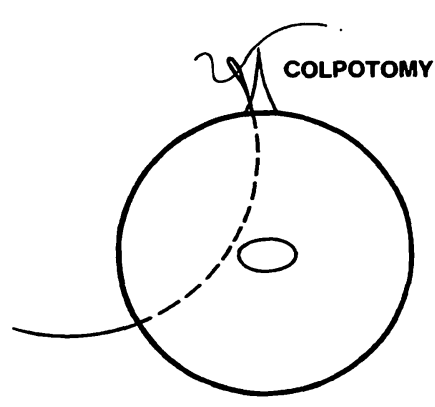

1.

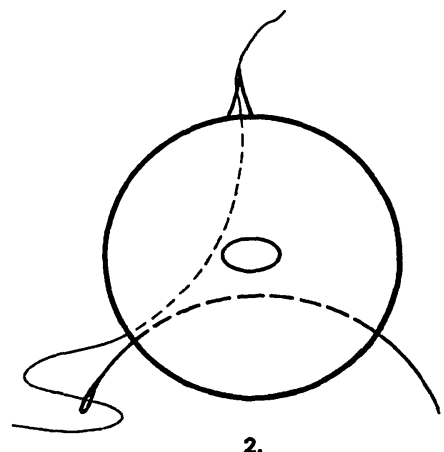

2.

The principle of closing amniotic leaks is as follows:

By the application of a fibrin clot, the leakage of amniotic fluid is interrupted, thus promoting regeneration of chorion and amnion and their close contact with the decidua. Direct closure of the ruptured membranes is not attained.

The fibrinogen solution is clotted by thrombin $(500 \mathrm{IU} / \mathrm{ml})$. The fibrin clot is stabilized by polymerization of fibrin monomers as in the second stage of blood coagulation; fibrinolysis is inhibited by the addition of proteinase inhibitors.

From the literature and preliminary trials, we had gained the impression that no or only an insufficient fibrin clot is formed when the cervical canal is open, as the clot is flushed out prematurely by the flow of amniotic fluid. Accordingly, before applying the sealant, we place a cerclage by the reverse MCDONALD procedure

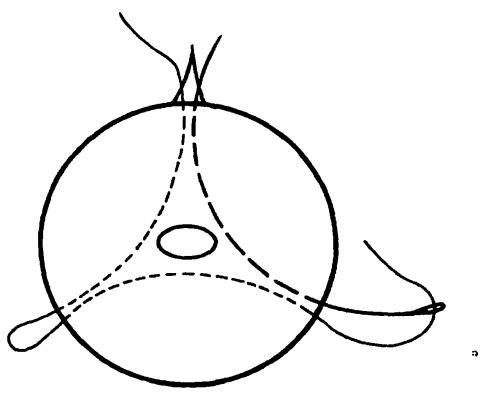

3.

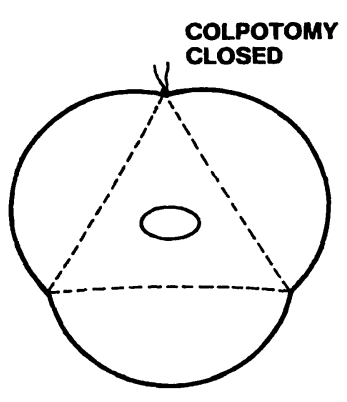

4.

ORIGINAL MC DONALD TECHNIQUE

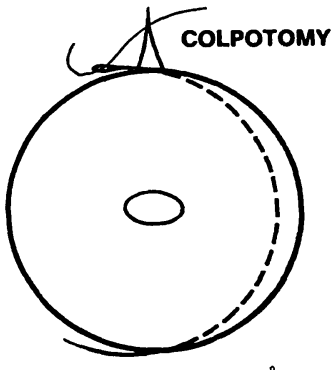

1.

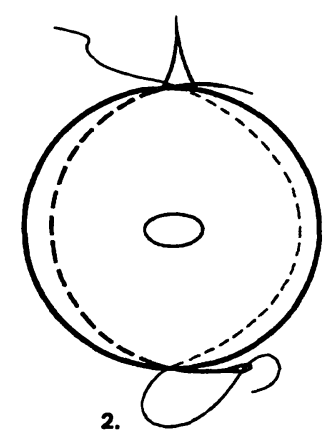

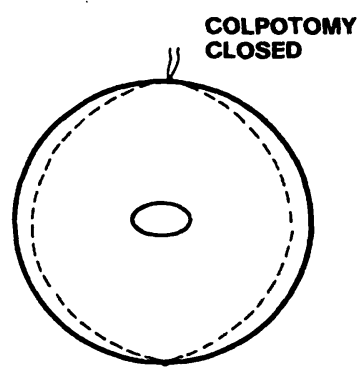

3.

OWN TECHNIQUE : - "REVERSE MC DONALD “

Figure 1. Modified cerclage technique (reverse McDonald procedure). 
which was first published by the author in 1965 [2]. This technique has the advantage that after minor anterior colpotomy and retraction of the bladder, a double thread can be wound around the cervix at the level of the internal os uteri thus keeping trauma to the cervix to a minimum. Passing the needle and thread parallel to the tunica vaginalis, a single inward and outward stitch is inserted and then the thread is turned $360^{\circ}$ around the cervix (figure 1). At the onset of labor the pressure of the thread on the isthmus uteri is evenly distributed in contrast to the MCDonald technique in which the thread exerts a saw-like effect and prematurely cuts through the tissue (figure 1).

To apply TissuCOL ${ }^{\circledR}$ we routinely use the DuPLoJECT double syringe clip (figure 2). This method has the advantage that the two sealant components are contained in separate syringes which are operated simultaneously. Equal volumes of both components are mixed in the y-shaped joining piece before being ejected. A short blunt needle is attached to the joining piece which, after dilatation of the external os uteri using 4 pairs of Allis forceps, can be introduced through the loop encircling the cervix behind which the fibrin clot is applied without trauma

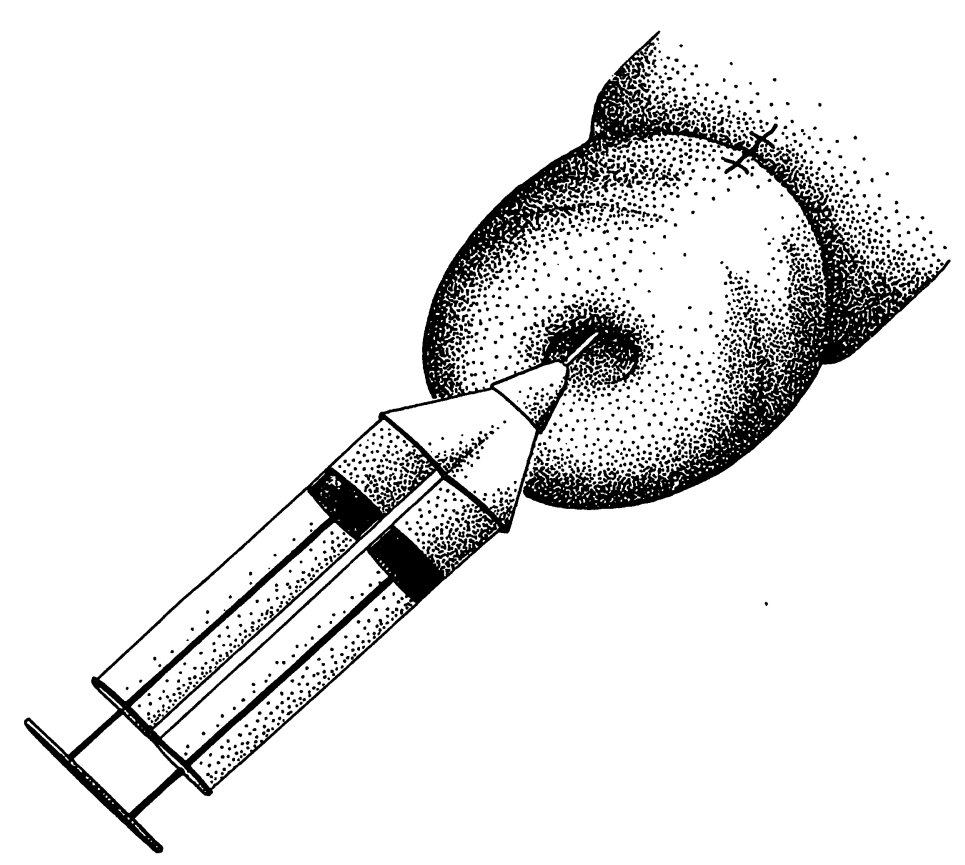

Figure 2. Duploject double syringe for application of fibrin sealant. One syringe contains fibrinogen solution, the other thrombin combination. to the external os uteri. In this way extremely long and pronounced elevation of the pelvis is no longer necessary and the patient can be returned to her bed after 3 minutes.

As direct adhesion of the fibrin sealant to the cervical wall is not to be expected, we consider cerclage before application of the fibrin clot to be essential in order to keep the flow of amniotic fluid to a minimum. The sealant mixture ejected from the syringe clip results in a clot which remains in place for at least 10 days. This was reported by GENZ in 1980 [8] following his in vitro experiments which we can fully corroborate. Initially, TissucoL ${ }^{\circledR}$ application was repeated as soon as amniotic fluid was again seen to escape, despite successful sealing; for this repeated sealing procedure no anesthesia was necessary. The anterior and posterior labia of the os uteri were grasped and separated with 2 pairs of Allis forceps, and $1 \mathrm{ml} \mathrm{Tissucol}{ }^{\circledR}$ was applied using the DuploJeCr syringe clip. If after 24 hours from the first sealing, the patient's sanitary napkin was not completely dry, another sealing was performed and repeated up to 6 times. At present, we apply the sealant 3 times at intervals of 24 hours.

\section{Results}

Figure 3 demonstrates the prolongation of pregnancy after the first application of sealant. Each column represents a single case; the black colums represent patients whose infants were alive at birth or survived the first week of life; the shaded columns represent infants who died in utero or within the first week of life. It is evident from this table that most patients (i. e. 13) were first treated between the 26th and the end of the 33th week of pregnancy and also that during this period of gestation the fewest fetal losses occurred. The pregnancy which was prolonged most continued for more than 172 days after the first application of sealant, the shortest for just 3 days after attempting to seal the amniotic leak.

Figure 4 comprises the birth weights of neonates after TrssuCOL ${ }^{\circledR}$ sealing, irrespective of the 
TISSUCOL ${ }^{\circledR}$

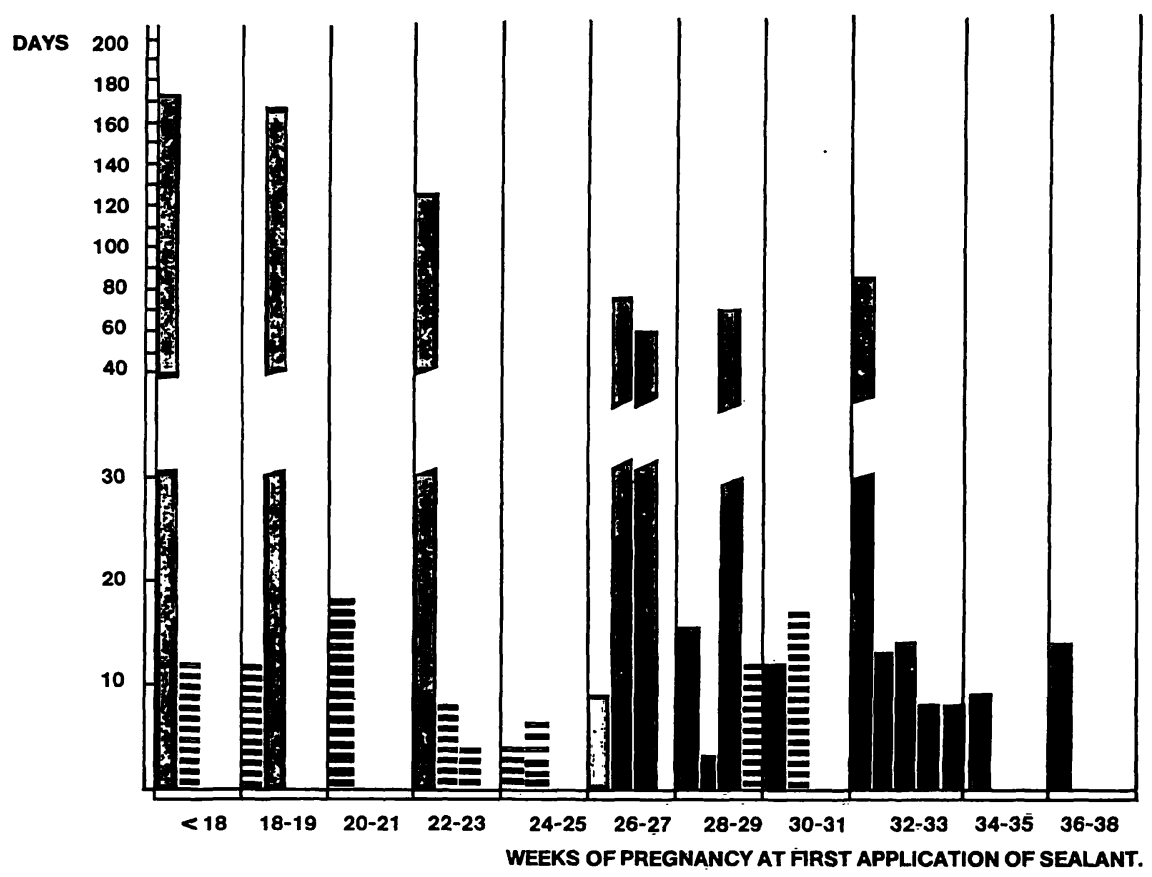

a ALIVE

Figure 3. Prolongation of pregnancy after first application of sealant.

TISSUCOL ${ }^{(B)}$

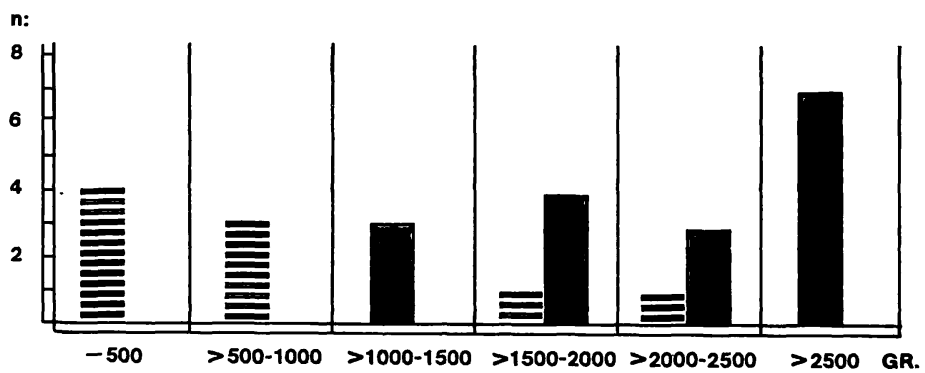

1 ALIVE $\equiv$ DEAD

Figure 4. Birth weights of neonates after Tissucol ${ }^{\circledR}$ sealing, irrespective of the duration of pregnancy from the time of the first sealant application.

duration of pregnancy at the time of the first sealant application. Of these 26 pregnancies 17 infants survived. Nine infants died (1 having a birth weight of $1,680 \mathrm{~g}$, and 1 of 2,240 g).

All the other infants who died had birth weights of less than $820 \mathrm{~g}, 4$ of them below $400 \mathrm{~g}$. Surprisingly, none of the surviving children developed RDS. A single child died post partum from the sequelae of RDS; this was a breech presentation weighing $1,650 \mathrm{~g}$ due to severe placental insufficiency who was delivered by cesarean section in the $32 \mathrm{nd}$ week of pregnancy.

Cortisone was administered intravenously to all women when it become evident that the pregnancy could not be prolonged. Parturition was postponed for at least 12 hours by massive tocolytic treatment. Twentyfive infants were delivered spontaneously, and 3 were delivered by cesarean section.

\section{Discussion}

Although a few in vitro experiments have been performed, [7] the mechanism of action of the fibrin clot in premature rupture of the membranes is not yet fully understood. Closure of the spontaneously ruptured amniotic membranes cannot be achieved with certainty, nor can this be expected since the leak can hardly ever be located when blind sealing of the lower amniotic pole is attempted. Critically speaking, we cannot claim that in our group of 26 patients TissuCOL ${ }^{\circledR}$ sealing has been successful, as long as no criteria for the evaluation of success or 
failure of such intervention have been agreed upon. Due to the fact that 17 alive or surviving children were born of 26 patients, a success rate of $65 \%$ was achieved. GeNZ [9-12] reported similar results. Since the whole series of sealings were performed beyond the 32nd week of pregnancy, the question arises as to whether these were sufficiently justified because the survival rate in hospitals with optimal neonatal care will by no means be lower providing the patients had received tocolytic treatment as long as possible. It has been observed that rupture of the membranes prior to the 28 th week is linked with a perinatal mortality of $50 \%$, and we have registered 5 infants who survived and just as many who died among our patients in whom rupture of the membranes occurred between the 16th and the 28th week. This makes us question the observation of GENZ that sealing of the amniotic membranes in the 1st trimester or the 1st half of the second trimester of pregnancy is most successful.

Our results do not confirm this assertion, and the total number of cases from all publications is too small to permit definite conclusions. Possibly, the period by which pregnancy is prolonged after the first sealing is the best criterion of success. When a minimum period of 28 days is considered as a successful prolongation of pregnancy, this period has been considerably exeeded in 6 of our 26 cases, and all 6 patients had live and surviving infants. If from our

\section{Summary}

The description of a new technique for fibrin adhesion (in 28 patients) for premature rupture of the membranes in pregnancy is reported. Unless cerclage has been carried out earlier, it is necessary to suture the cervical canal immediately after rupture of the membranes in order to be able to insert a fibrin clot. The author's modified cerclage technique (reverse McDoNALD procedure) is described. The advantages are minimal trauma to the lower uterine segment and a somewhat physiologic fixation of the synthetic suture material. For application of the fibrin sealant, the DUPLOJECT syringe clip is used, as patients all cases are excluded who were treated with Tissucol ${ }^{\oplus}$ after the 32nd week, there are 6 successful prolongations as opposed to 11 failures in the remaining patients. This would be a success rate of $35 \%$, whatever this figure may mean.

Amniotic infection syndrome was not observed in any of our cases. None of our patients had temperatures of more than $37.5^{\circ} \mathrm{C}$ in pregnancy or labor, nor did positive $\mathrm{HB}_{\mathrm{s}}$ antigen or antibody findings occur within 6 months after the last sealant application. With respect to a possible hepatitis hazard, the author will report elsewhere on a study of 100 cases receiving Tissucol treatment in obstetrics and gynecology (BAUMGARTEN, in preparation). In all cases in whom labor started prematurely in spite of TissuCOL ${ }^{(1)}$ sealing after premature rupture of the membranes, betamimetic agents were given for massive intravenous tocolysis without oral longterm therapy.

The manner in which the Trssucol ${ }^{\circledR}$ clot seals a leaking amniotic sac is completely unknown. Admittedly, our case number is small, the attempt to close prematurely ruptured membranes by fibrin adhesion appears justified in view of the lack of complications of the treatment for mother and child and in view of the 17 live and surviving infants in our study. Further investigations will be necessary to clarify in which period of pregnancy such attempts are likely to yield good results.

it allows exact dosage and blending of the two sealant components in the course of their application to the site of sealing.

The problem of evaluation of the results of the procedure is discussed. The technique carries no risk to mother or child. No cases of amniotic infection syndrome have been observed. Through prolongation of the pregnancy, time is gained for maturation of the fetal lungs. Accordingly, the authors recommend the technique for treating premature rupture of the membranes, although there is as yet no definite answer as to the optimal timing of this adhesion treatment during pregnancy.

Keywords: Amniotic fluid, cerclage techniques, fibrin adhesion, premature labor, premature rupture of membranes. 


\section{Zusammenfassung}

Die Technik der Fibrinklebung bei vorzeitigem Blasensprung während der Schwangerschaft

Anhand von 28 Fällen versuchen wir die Brauchbarkeit eines humanen Fibrinklebers zum Verschluß des unteren Blasenpoles bei vorzeitigem Blasensprung $\mathrm{zu}$ untersuchen. Bevor ein Gramm Tissucol ${ }^{\circledR}$ in der Höhe des unteren Blasenpoles appliziert wird, wird eine Cerclage vorangestellt. Die hierfür verwendete Technik entspricht einer eigenen Modifikation, die „umgekehrte McDoNALD Technik“ genannt wird. Sie wird im Detail beschrieben und hat den Vorteil, daß bei nur einmaligem Ein- und Ausstechen der Druck des Fadens überall in der Höhe des innerern Muttermundes gleich stark ist und ein Durchschneiden dadurch weitgehend verhindert wird. Für die Applikation des Fibrinklebers wird die DuPloJeCr-Spritze verwandt, da sie genaue Dosierung und Durchmischung der Kleberkomponenten am Applikationsort gewährleistet.

Über den Wirkungsmechanismus des humanen Gewebsklebers bei dieser Art der Behandlung wird diskutiert. Die Technik birgt keine Risiken für Mutter oder Kind. Fruchtwasserinfektionen wurden nicht beobachtet. Durch die Schwangerschaftsverlängerung wird Zeit für die fetale Lungenreifung gewonnen. Aufgrund der Ergebnisse kommen wir zum Schluß, daß die Methode im zweiten Drittel der Schwangerschaft wert ist, versucht zu werden. Bèi vorzeitigem Blasensprung jenseits der 28 . Woche sind die Ergebnisse nicht zufriedenstellend.

Schlüsselwörter: Cerclage, drohende Frühgeburt, Fruchtwasser, Gewebskleber, vorzeitiger Blasensprung.

\section{Résumé}

Technique de l'adhérence de fibrine lors de la rupture prématurée des membranes au cours de la grossesse Les auteurs rapportent une nouvelle technique d'adhérence de fibrine chez 28 patientes avec une rupture précoce des membranes au cours de la grossesse. Il est nécessaire d'effectuer un cerclage immédiatement après la rupture des membranes afin de pouvoir appliquer un caillot de fibrine, à moins que ce cerclage ait été déjà effectué auparavant. Les auteurs décrivent leur technique modifiée du cerclage (technique inverse de MACDoNALD); cette technique présente l'avantage d'entraîner un traumatisme minime du segment inférieur et de permettre une fixation plus physiologique du matériel synthétique de suture. On utilise la seringue Duploject pour l'application du bouchon de fibrine, ce qui permet un dosage précis et un écoulement à déquat des 2 composants pendant leur application sur le site d'obturation. Le problème de l'évaluation des résultats du procédé est discuté. La technique n'entraîne pas de risque pour la mère ou l'enfant, il n'a pas été observé de cas d'infection amniotique et, grâce à la prolongation de la grossesse, on gagne du temps pour la maturation pulmonaire fœtale; c'est pourquoi les auteurs recommendent cette technique pour traiter la rupture prématurée des membranes, bien qu'il n'y ait pas encore de réponse précise concernant le timing optimal du traitement par adhérence au cours de la grossesse.

Mots-clés: Accouchement prématuré, adhérence de fibrine, liquịde amniotique, rupture prématurée des membranes, techniques du cerclage.

\section{References}

[1] ANGER, H.: Fibrinklebung bei vorzeitigem Blasensprung. „Die gelben Hefte“ XXIV (1984) Boehringer, Med. Verlagsges., Marburg

[2] BAUMgarten, K.: Kritische Betrachtungen zur Indikation und Operationstechnik bei Zervixinsuffizienz. Geburtshilfe Frauenheilkd. 3 (1965) 260

[3] BREESE, M. W.: Spontaneous premature rupture of membranes. Am. J. Obstet. Gynecol. 81 (1961) 1086

[4] Brun del Re, R., P. De Grandi, V. Gulik, H. A. HirsCh, M. HinselmanN, M. S. Ramzin: Vorzeitiger Blasensprung, intrauterine Infektion, RDS bei Frühgeborenen. In: Dudenhausen, J. W., E. SALING, E. ScHMmt (eds.): Perinatale Medizin, Bd. VI. Thieme, Stuttgart 1975
[5] Cronkite, E. P., E. L. Lozner, J. M. Deaver: Use of thrombin and fibrinogen in skin grafting. J. A. M. A. 124 (1944) 976

[6] Fettig, O., R. Heilmann: Fibrinklebung bei vorzeitigem Blasensprung $-\mathrm{Z}$. Geburtshilfe Perinatol. 185 (1981) 94

[7] GeNZ, H.-J.: Die Behandlung des vorzeitigen Blasensprungs durch Fibrinklebung. Med. Welt 42 (1979) 1557

[8] Genz, H.-J., H. Gerlach, H. Metzger: Behandlung des vorzeitigen Blasensprunges durch Fibrinklebung. In: DeutsCH, E., K. LECHNER: Fibrinolyse, Thrombose u. Haemostase, Schattauer Verlag, Stuttgart, New York 1980 
[9] GeNZ, H.-J., H. LuDwIG: Weitere Erfahrungen mit der Fibrinklebung bei schwangeren Frauen und vorzeitigem Blasensprung. Blut 42 (1981) 122

[10] GENZ, H.-J., H. LuDwiG: Weitere Ergebnisse mit der Fibrinklebung bei schwangeren Frauen und vorzeitigem Blasensprung. In: BLÜMEL, G., S. HAAS: Mikrocirculation und Prostaglandinstoffwechsel. Neues über Fibrin und Fibrinkleber, Schattauer Verlag Stuttgart, New York 1981

[11] Genz, H.-J., H. Ludwig, H. Metzger, E. RosenTHAL, H. GerLACH: Antibiotikahaltiger Fibrinkleber zur Behandlung des vorzeitigen Blasensprungs in Perinatale Medizin. In: Dudenhausen, J. W., E. SALING (eds.): Perinatale Medizin, Band IX, Thieme, Stuttgart 1982

[12] GENZ, H.-J.: Möglichkeiten der konservierenden Behandlung des vorzeitigen Blasensprungs. In: LudWIG, H., L. HeIlmanN: Ergebnisse des Hexoprenalinsymposiums. Wehenhemmung. Springer Verlag Berlin, New York 1982

[13] GunN, G. C., D. R. Mishell, D. G. Morton: Premature rupture of the fetal membranes. A review. Am. J. Obstet. Gynecol. 106 (1970) 469

[14] Jones, M. D., L. I. BuRD, W. A. Bowes, F. C. BATTAGLIA, L. O. LUBCHENCO: Failure of association of premature rupture of membranes with respiratory distress syndrome. N. Engl. J. Med. 292 (1975) 1253

[15] KURZ, C. S., A. HuCh: Fibrin Sealing. An advanced therapy in dealing with premature rupture of membranes. J. Perinat. Med. 10 (1982) 66

[16] Lebherz, T. B., I. P. HellmanN, R. Madding, A. ANCTIL, S. L. ARJE: Double-blind study of premature rupture of the membranes. Am. J. Obstet. Gynecol. 87 (1963) 218
[17] Ludwig, H., H.-J. GenZ, H. Gerlach, H. MetzGER: Behandlung von Eihautlecks im 2. Trimenon durch Fibrinversiegelung des unteren Eipoles. Arch. Gynecol. 232 (1981) 466

[18] Matras, H., H. Kuderna: Glueing Nerve Anastomoses with Clotting Substances. Kongreß für plastische und rekonstruktive Chirurgie, Paris 1975

[19] Sell, E. J., T. R. HARRIS: Association of premature rupture of membranes with idiopathic respiratory distress syndrome. Obstet. Gynecol. 49 (1977) 167

[20] Thibeault, D. W., G. C. Emmanouilides: Prolonged rupture of fetal membranes and decreased frequency of respiratory distress syndrome and patent ductus are riousus in preterm infants. Am. J. Obstet. Gynecol. 129 (1977) 44

[21] TIDrICK, R. T., E. D. WARNeR: Fibrin fixation of skin transplants. Surgery 15 (1944) 90

[22] WeBB, G. A.: Maternal death associated with premature rupture of the membranes. Am. J. Obstet. Gynecol. 98 (1967) 594

[23] WEBSTER, A.: Management of premature rupture of the fetal membranes. Obstet. Gynecol. Surv. 24 (1969) 485

[24] Worthington, D., A. H. A. Maloney, B. T. SMITH: Fetal lung maturity. I. Mode of onset of premature labor. Influence of premature rupture of the membranes. Obstet. Gynecol. 49 (1977) 275

Received October 19, 1984. Revised February 25, 1985. Accepted March 8, 1985.

Prof. Dr. K. Baumgarten

Geburtshilflich-gynäkologische Abteilung des Wilhelminenspitals der Stadt Wien Montleartstraße 37

A-1171 Wien 